\title{
Zrównoważony marketing w zrównoważonym świecie - cz. 2
}

\author{
Sustainable marketing in a sustainable world — part 2
}

\author{
doc. dr Jacek Kamiński \\ Państwowa Szkoła Wyższa im. Papieża Jana Pawła II w Białej Podlaskiej \\ ORCID: 0000-0001-7376-8190 \\ e-mail: jacek_kaminski@vp.pl
}

\begin{abstract}
W powszechnym odbiorze dominuje pogląd, że marketing i zrównoważony rozwój to pojęcia od siebie dość odległe. Tymczasem związek marketingu i zrównoważonego rozwoju jest wyjątkowo silny. Wynika z funkcji pełnionych przez marketing w gospodarce i społeczeństwie, polegających na kojarzeniu dóbr i potrzeb na rynku oraz aktywności w sferze kreowania i zaspokojenia pragnień i oczekiwań konsumentów w celu osiągania przez nich satysfakcji oraz podniesienia jakości życia. Koncepcją, która najpełniej odzwierciedla zainteresowanie marketingu zrównoważonym rozwojem oraz otwiera marketing na dorobek nauk o zrównoważeniu (sustainable science), jest zrównoważony marketing (sustainable marketing/sustainability marketing). Celem artykułu jest scharakteryzowanie tej marketingowej koncepcji oraz wyjaśnienie, w jakim zakresie wpływa ona na przedefiniowanie założeń tradycyjnego marketingu. Artykuł składa się z dwóch części. W pierwszej wyjaśniono, dlaczego marketing nie może być obojętny wobec kwestii środowiskowych, omówiono bariery tego zainteresowania oraz związaną z nim tradycję. W drugiej przedstawiono założenia zrównoważonego marketingu, prezentując go jako koncepcję makromarketingową, która wymaga zasadniczego przedefiniowania tradycyjnego marketingu oraz wprowadzenia istotnych zmian w zarządzaniu marketingowym. W zakończeniu sformułowano wnioski wynikające z przeprowadzonej analizy, dotyczące miejsca, specyfiki i znaczenia problematyki środowiskowej w nauce o marketingu.
\end{abstract}

Keywords

marketing, zrównoważony marketing, teoria marketingu, historia myśli ekonomicznej, ekonomia środowiskowa

There is a common perception of marketing and sustainable growth to be two concepts which are rather distant from one another. Yet, the relationship between marketing and sustainable growth is remarkably strong. It stems from the functions fulfilled by marketing in the economy and in the society, which consist of matching the goods and the demands on the market as well as activities in the area of creation and fulfillment of desires and expectations of consumers in order to reach their satisfaction and lift their quality of life. The concept which reflects the interest of marketing with a sustainable growth most fully and opens marketing up to the achievements of sciences about sustainability (sustainable science) is sustainable//sustainability marketing. The objective of the article is to characterize this marketing concept and explain in what scope it impacts redefining the assumptions of traditional marketing. The article consists of two parts. The first part encompasses explanations as to why the marketing may be indifferent towards environmental matters, further to the analysis of barriers of this interest and the tradition related to them. The second part presents the assumptions of sustainable marketing, presenting it as the macro-marketing concept which requires fundamental redefining of traditional marketing and introducing significant changes in the marketing management. Conclusions were drawn in the final part which stem from the carried out analysis concerning the place, the specificity and the meaning of the environmental problem in marketing science.

\section{Slowa kluczowe}

marketing, sustainable marketing, marketing theory, history of economic thought, environmental economics

JEL: B0, M3, Q5

Str. 3-16 


\section{Bibliografia}

Achrol, R. i Kotler, P. (2012). Frontiers of the Marketing Paradigm in the Third Millennium. Journal of the Academy of Marketing Science, 40(1), 35-52. https://doi.org/10.1007/s11747-011-0255-4

Belz, F.-M. i Peattie, K. (2012). Sustainability Marketing. A Global Perspective. Chichester: Wiley.

Brzustewicz, P. (2010). Marketing zrównoważony jako źródło przewagi konkurencyjnej. Handel Wewnętrzny, (6), 11-19.

Burgiel, A. i Zrałek, J. (2018). Konsumowanie bez posiadania (non-ownership consumption) jako przejaw ewolucji spożycia — determinanty i szanse rozwoju w Polsce. Handel Wewnętrzny, 3(374), 70-81.

Drucker, P. F. (1958). Marketing and Economic Development. Journal of Marketing, 22(3), 252-259. https://doi.org/ $10.1177 / 002224295802200302$

Hunt, S. D. (2011). Sustainable Marketing, Equity, and Economic Growth: A Resource-Advantage Economic Freedom Approach. Journal of the Academy of the Marketing Science, 39, 7-20. https://doi. org/10.1007/s11747-010-0196-3

Kilbourne, W. E., McDonagh, P. i Prothero, A. (1997). Sustainable Consumption and The Quality of Life: A Macromarketing Challenge to the Dominant Social Paradigm. Journal of Maromarketing, 17(1), 4-24. https://doi.org/10.1177/027614679701700103

Kilbourne, W., McDonagh, P. i Prothero, A. (2018). Sustainable consumption, consumer culture and the politics of a megatrend. W: O. Kravets, P. Maclaran, S. Miles i A. Venkaters (red.), The Sage Handbook of Consumer Culture (478-498). London: Sage Publications.

Lauterborn, R. (1990). New Marketing Litany: 4P's Passe, C-Words Take Over. Advertising Age, 61(41).

Martin, D. M. i Schouten, J. W. (2014). Sustainable Marketing. Upper Saddle River, NJ.: Pearson Prentice Hall.

Mish, J. i Miller, A. (2014). Marketing's Contributions to Sustainable Society. W: P. E. Murphy i J. F. Sherry, Jr (red.), Marketing and Common Good. Essays from Notre Dame on Societal Impact (152-174). Abindon: Routlege.

Mitchell, R., Wooliscroft, B. i Higham, J. (2010). Sustainable Market Orientation: New Approach to Managing Marketing Strategy. Journal of Macromarketing, 30(2), 160-170. https://doi.org/10.1177/0276146710361928

Naisbitt, J. (1982). Megatrends: Ten New Directions Transforming Our Lives. New York: Warner Books.

Natural Step. (2009). United States Sustainability Primer: Step By Natural Step. Pozyskano z: http://www.naturalstepusa.org/ storage/case-studies/Primer_USEdition_print_072009.pdf

Pabian, A. (2017). Zrównoważona sprzedaż osobista. Marketing i Rynek, (10), 5-11.

Peattie, K. (1992). Green Marketing. London: Pitman.

Peattie, K. (2007). Sustainable marketing: Marketing re-thought, re-mixed and re-tooled. W: M. Saren, P. Maclaran, Ch. Goulding, R. Eliot, A. Shankar i M. Catterall (red.), Critical Marketing: Defining the Field. Oxford: Elsevier.

Peattie, K. i Belz, F.-M. (2010). Sustainability Marketing — an Innovative Conception of Marketing. Marketing Review of St. Gallen, 27(5), 8-15. https://doi.org/10.1007/s11621-010-0085-7

Porter, M. E. (1991). America's Green Strategy. Scientific American, 264(April).

Porter, M. E. i van der Linde, C. (1995). Green and Competitive: Ending the Stalemate. Harvard Business Review, 73(5), $120-133$.

Van Dam, Y. K. i Apeldoorn, P. A. C. (1996). Sustainable Marketing. Journal of Macromarketing, (Fall), 45-56. https://doi.org/10.1177/027614679601600204

Vargo, S. L. i Lusch, R. F. (2004). Evolving to a New Dominant Logic for Marketing. Journal of Marketing, 68, 1-17. https://doi.org/10.1509/jmkg.68.1.1.24036

Visser, W. (2007). Sustainability. W: W. Visser, D. Matten, M. Pohl i N. Tolhust (red.), The A to Z of Corporate Social Responsibility. West Sussex: John Wiley \& Sons.

Wymer, W. i Polonsky, M. J. (2015). The Limitations and Potentialities of Green Marketing. Journal of Nonprofit \& Public Sector Marketing, 27(3), 239-262. https://doi.org/10.1080/10495142.2015.1053341

Zaremba-Warnke, S. (2016). Marketing zrównoważony vs. niezrównoważona konsumpcja. Studia Ekonomiczne. Zeszyty Naukowe Uniwersytetu Ekonomicznego w Katowicach, 255, 92-101. 